\title{
Cytotoxic aromatic compounds from Hericium erinaceum
}

\author{
Bing-Ji Ma, Hai-You Yu, Jin-Wen Shen, Yuan Ruan, Xu Zhao, Han Zhou and Ting-Ting Wu
}

The Journal of Antibiotics (2010) 63, 713-715; doi:10.1038/ja.2010.112; published online 6 October 2010

Keywords: hericenone I; hericene D; Hericium erinaceum; mushroom

Hericium erinaceum is a mushroom belonging to the family Hericiaceae and has been used as medicine or food in China and Japan without harmful effects. $H$. erinaceum grows on old or dead broadleaf trees and has been used as medicine for treatment of gastricism in traditional Chinese medicine for more than 1000 years. Recently, the chemical constituents of $H$. erinaceum have been investigated for its interesting and significant bioactivities. ${ }^{1,2}$ Hericenones A and B were isolated from the fruiting body of $H$. erinaceum as cytotoxic principles against Hela cells. ${ }^{3}$ Hericenones C, D and E exhibited stimulating activity to the synthesis of nerve growth factor in vitro. ${ }^{4-7}$ In the presence of hericenones $\mathrm{C}, \mathrm{D}, \mathrm{E}$ and $\mathrm{H}$ at $33 \mu \mathrm{g} \mathrm{ml}^{-1}$, mouse astroglial cells secreted $23.5 \pm 1.0,10.8 \pm 0.8$, $13.9 \pm 2.1$ and $45.1 \pm 1.1 \mathrm{pg}$ per $\mathrm{ml}$ nerve growth factor into the culture medium, respectively. The degree of activity for hericenone $\mathrm{D}$ was almost at the same level as that of a potent stimulator, epinephrine. It is of interest that the difference in activity among those compounds was dependent on the nature of the fatty acid. These results suggest the usefulness of $H$. erinaceum for the treatment and prevention of dementia.

In the course of our continuing search for new active compounds from mushroom, we found two new aromatic compounds, namely hericenone I and hericene D. In this report, we described the isolation, structural elucidation and cytotoxic activity of hericenone I and hericene D (Figure 1).

The $\mathrm{CHCl}_{3}$-soluble fraction of $\mathrm{MeOH}$ extract from the fruiting bodies of $H$. erinaceum was subjected to repeated chromatography to yield hericenone I and hericene D. Hericenone I was obtained as a white oil. The HRESI-MS of hericenone I gave an ion $[\mathrm{M}+\mathrm{Na}]^{+}$peak at $m / z 619.6686$ (calc. for $\mathrm{C}_{37} \mathrm{H}_{56} \mathrm{O}_{6} \mathrm{Na} 619.6702$ ) and corresponded to a molecular formula of $\mathrm{C}_{37} \mathrm{H}_{56} \mathrm{O}_{6}$. The IR spectrum indicated the presence of a hydroxyl group at $3463 \mathrm{~cm}^{-1}$ and an $\alpha, \beta$-unsaturated ketone $\left(1669 \mathrm{~cm}^{-1}\right)$. The ${ }^{13} \mathrm{C}$ and DEPT-NMR spectrum of hericenone I was quite similar to that of hericenone $\mathrm{D}$, except for the presence of two more olefinic $\mathrm{CH}$ groups $(129.7, \mathrm{CH} ; 130.0, \mathrm{CH}){ }^{4}$ The ${ }^{1} \mathrm{H}$ NMR spectrum of hericenone I showed the signals of three methines at $\delta 5.37(1 \mathrm{H}, \mathrm{t}, J=7.2 \mathrm{~Hz}), 6.15(1 \mathrm{H}, \mathrm{s})$ and $\delta 6.54(1 \mathrm{H}, \mathrm{s})$; four methyls at $\delta 0.86(3 \mathrm{H}, \mathrm{t}, J=7.0 \mathrm{~Hz}), \delta 1.78(3 \mathrm{H}, \mathrm{s}), \delta 1.83(3 \mathrm{H}, \mathrm{s})$ and $\delta 2.16(3 \mathrm{H}, \mathrm{s})$; and one methoxyl at $\delta 3.91(3 \mathrm{H}, \mathrm{s})$, together with one $\mathrm{CHO}$ group at $\delta 10.20(1 \mathrm{H}, \mathrm{s})$ (Table 1). Methanolysis of hericenone I gave the methyl ester of oleic acid, which was identified by GC-MS. Considering the molecular formula of hericenone I, it was supposed to be an oleic ester of hericenone. The construction of molecular framework was deduced from the ${ }^{1} \mathrm{H}-{ }^{1} \mathrm{H}$ COSY, heteronuclear multiple quantum coherence and heteronuclear multiple bond coherence spectra (Figure 2).

Hericene D was also obtained as a white oil. The HRESI-MS of hericene $\mathrm{D}$ gave an ion $[\mathrm{M}+\mathrm{Na}]^{+}$peak at $\mathrm{m} / z 603.4026$ (calc. for $\mathrm{C}_{37} \mathrm{H}_{56} \mathrm{O}_{5} \mathrm{Na}$ 603.4031) and corresponded to a molecular formula of $\mathrm{C}_{37} \mathrm{H}_{56} \mathrm{O}_{5}$, requiring 10 degrees of unsaturation. The IR spectrum indicated the presence of a hydroxyl group at $3446 \mathrm{~cm}^{-1}$. The ${ }^{13} \mathrm{C}$ and DEPT-NMR spectrum of hericene D was similar to that of hericene A, except for the presence of four more olefinic $\mathrm{CH}$ groups $(\delta 127.9, \mathrm{CH}$; 128.1, CH; 130.0, CH; 130.2, CH). ${ }^{6}$ The ${ }^{1} \mathrm{H}$ NMR spectrum of hericene D showed the signals of three methines at $\delta 5.05(1 \mathrm{H}, \mathrm{t}$, $J=7.0 \mathrm{~Hz}), 5.17(1 \mathrm{H}, \mathrm{t}, J=8.0)$ and $\delta 6.53(1 \mathrm{H}, \mathrm{s})$; four methyls at $\delta$ $0.87(3 \mathrm{H}, \mathrm{t}, J=7.0 \mathrm{~Hz}), \delta 1.60(3 \mathrm{H}, \mathrm{s}), \delta 1.63(3 \mathrm{H}, \mathrm{s})$ and $\delta 1.77(3 \mathrm{H}, \mathrm{s})$; and one methoxyl at $\delta 3.91(3 \mathrm{H}, \mathrm{s})$, together with one $\mathrm{CHO}$ group at $\delta 10.10(1 \mathrm{H}, \mathrm{s})$ (Table 2). Methanolysis of hericene D yielded the methyl ester of linoleic acid, which was also identified by GC-MS. Considering the molecular formula, hericene $\mathrm{D}$ was deduced to be a linoleic ester of hericene.

Compounds $\mathbf{1}-\mathbf{5}$ were tested in vitro for cytotoxic activity against tumor cells by MTT assay. All the compounds showed cytotoxic activity against EC109 cell line, and the cell growth inhibitor percentages of compounds 1-5 on EC109 cell line are shown in Table 3.

It may be pointed out that hericenone $\mathrm{I}$ and hericene $\mathrm{D}$ have a structure related to mycophenolic acid, an antibiotic produced by Penicillium spp. ${ }^{6}$ Hericenone and hericene D were both tested against the bacteria, Staphylococcus aureus, Bacillus thuringiensis, Escherichia coli, Bacillus megaterium and Bacillus subtilis at $1 \mathrm{mg} \mathrm{ml}^{-1}$, respectively. However, hericenone I and hericene D showed only weak antibacterial 
<smiles>COc1cc(CO)c(C=O)c2c1CCC(C)(CC(=O)C=C(C)C)O2</smiles>

$1 \mathrm{R}=$ palmytoyl<smiles>COc1cc(CO)c(C=O)c(O)c1[CH]C=C(Br)CC(=O)C=C(C)C</smiles>

$2 \mathbf{R}=$ palmytoyl

$3 \mathbf{R}=$ oleoyl<smiles>COc1cc(CO)c(C=O)c(O)c1CC=C(C)CCC=C(C)C</smiles>

$4 \mathbf{R}=$ palmytoyl

$5 \mathbf{R}=$ linoleoyl

Figure 1 Structures of compounds 1-5.

Table $1{ }^{1} \mathrm{H}$ and ${ }^{13} \mathrm{C}$ NMR data of herienone I in $\mathrm{CDCl}_{3}$

\begin{tabular}{|c|c|c|}
\hline Position & $\delta C$ & $\delta H$ \\
\hline 1 & 138.7 & \\
\hline 2 & 112.9 & \\
\hline 3 & 162.9 & \\
\hline 4 & 117.3 & \\
\hline 5 & 163.5 & \\
\hline 6 & 105.6 & $6.54(1 \mathrm{H}, \mathrm{s})$ \\
\hline 7 & 62.9 & $5.18(2 \mathrm{H}, \mathrm{s})$ \\
\hline 8 & 193.1 & $10.20(1 \mathrm{H}, \mathrm{s})$ \\
\hline $1^{\prime}$ & 21.6 & $3.90(2 \mathrm{H}, \mathrm{d}, 7.2)$ \\
\hline $2^{\prime}$ & 126.3 & $5.37(1 \mathrm{H}, \mathrm{t}, 7.2)$ \\
\hline $3^{\prime}$ & 130.2 & \\
\hline $4^{\prime}$ & 55.6 & $3.02(2 \mathrm{H}, \mathrm{s})$ \\
\hline $5^{\prime}$ & 199.6 & \\
\hline $6^{\prime}$ & 122.3 & $6.15(1 \mathrm{H}, \mathrm{s})$ \\
\hline $7^{\prime}$ & 155.4 & \\
\hline $8^{\prime}$ & 27.5 & $1.83(3 \mathrm{H}, \mathrm{s})$ \\
\hline $9^{\prime}$ & 20.6 & $2.16(3 \mathrm{H}, \mathrm{s})$ \\
\hline $10^{\prime}$ & 16.4 & $1.78(3 \mathrm{H}, \mathrm{s})$ \\
\hline $1^{\prime \prime}$ & 173.1 & \\
\hline $2^{\prime \prime}$ & 34.2 & $2.35(2 \mathrm{H}, \mathrm{t}, 7.6)$ \\
\hline $9^{\prime \prime}, 10^{\prime \prime}$ & $129.7,130.0$ & $5.34(2 \mathrm{H}, \mathrm{m})$ \\
\hline $18^{\prime \prime}$ & 14.1 & $0.86(3 \mathrm{H}, \mathrm{t}, 6.8)$ \\
\hline $5-\mathrm{OCH}_{3}$ & 55.9 & $3.91(3 \mathrm{H}, \mathrm{s})$ \\
\hline
\end{tabular}

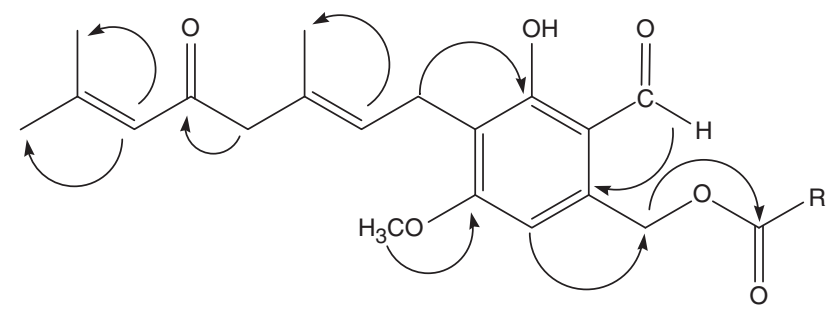

Figure 2 Key HMBC correlations of hericenone I.
Table $2{ }^{1} \mathrm{H}$ and ${ }^{13} \mathrm{C}$ NMR data of hericene $\mathrm{D}$ in $\mathrm{CDCl}_{3}$

\begin{tabular}{ccc}
\hline Position & $\delta C$ & $\delta \mathrm{H}$ \\
\hline 1 & 138.4 & \\
2 & 112.9 & \\
3 & 162.9 & \\
4 & 118.1 & \\
5 & 163.6 & $6.53(1 \mathrm{H}, \mathrm{s})$ \\
6 & 105.6 & $5.35(2 \mathrm{H}, \mathrm{s})$ \\
7 & 62.9 & $10.10(1 \mathrm{H}, \mathrm{s})$ \\
8 & 193.1 & $12.37(1 \mathrm{H}, \mathrm{s})$ \\
$3-\mathrm{OH}$ & & $3.34(2 \mathrm{H}, \mathrm{d}, 8.0)$ \\
$1^{\prime}$ & 21.4 & $5.17(1 \mathrm{H}, \mathrm{t}, 8.0)$ \\
$2^{\prime}$ & 121.2 & \\
$3^{\prime}$ & 131.2 & $1.97(2 \mathrm{H}, \mathrm{m})$ \\
$4^{\prime}$ & 39.8 & $2.04(2 \mathrm{H}, \mathrm{m})$ \\
$5^{\prime}$ & 26.7 & $5.05(1 \mathrm{H}, \mathrm{t}, 7.0)$ \\
$6^{\prime}$ & 124.4 & \\
$7^{\prime}$ & 135.7 & $1.63(3 \mathrm{H}, \mathrm{s})$ \\
$8^{\prime}$ & 25.6 & $1.60(3 \mathrm{H}, \mathrm{s})$ \\
$9^{\prime}$ & 17.6 & $1.77(3 \mathrm{H}, \mathrm{s})$ \\
$10^{\prime}$ & 16.1 & \\
$1^{\prime \prime}$ & 173.1 & $2.33(2 \mathrm{H}, \mathrm{t}, 8.0)$ \\
$2^{\prime \prime}$ & 34.2 & $5.37(4 \mathrm{H}, \mathrm{m})$ \\
$9^{\prime \prime}, 10^{\prime \prime}, 12^{\prime \prime}, 13^{\prime \prime}$ & $127.9,128.1,130.0,130.2$ & $0.87(3 \mathrm{H}, \mathrm{t}, 7.0)$ \\
$18^{\prime \prime}$ & 14.1 & $3.91(3 \mathrm{H}, \mathrm{s})$ \\
$5-\mathrm{OCH}_{3}$ & 55.9 & \\
\hline & & \\
\hline
\end{tabular}

activity in vitro against the five bacteria above. The damage of the $\gamma$-lactone ring in the structures of hericenone I and hericene D may be the main reason for the deficiency of antibacterial activity.

\section{EXPERIMENTAL PROCEDURE}

General

IR spectra were measured on a Bio-Rad FTS- 135 spectrometer with KBr pellets (Bio-Rad, Philadelphia, PA, USA). NMR spectra were recorded on a Brucker AV-400 spectrometer (Bruker Biospin, Fällanden, Switzerland) in $\mathrm{CDCl}_{3}$ solvent, with tetramethylsilane as the internal standard. MS were recorded on 
Table 3 Cell growth inhibitor percentages of compounds $1-5$ on EC109 cell line

\begin{tabular}{lcc}
\hline Compounds & Concentration $\left(\mathrm{moll}^{-1}\right)$ & Cell growth inhibitor (\%) \\
\hline $\mathbf{1}$ & $1 \times 10^{-3}$ & 65.34 \\
& $3 \times 10^{-4}$ & 36.68 \\
& $1 \times 10^{-4}$ & 33.75 \\
$\mathbf{2}$ & $1 \times 10^{-3}$ & 57.75 \\
& $3 \times 10^{-4}$ & 34.97 \\
& $1 \times 10^{-4}$ & 28.58 \\
$\mathbf{3}$ & $1 \times 10^{-3}$ & 59.23 \\
& $3 \times 10^{-4}$ & 48.06 \\
& $1 \times 10^{-4}$ & 41.33 \\
$\mathbf{4}$ & $1 \times 10^{-3}$ & 58.22 \\
& $3 \times 10^{-4}$ & 42.18 \\
& $1 \times 10^{-4}$ & 38.09 \\
$\mathbf{5}$ & $1 \times 10^{-3}$ & 50.12 \\
& $3 \times 10^{-4}$ & 45.66 \\
& $1 \times 10^{-4}$ & 32.27 \\
\hline
\end{tabular}

VG Auto-spec-3000 (VG, Manchester, UK) and API QSTAR Plusar spectrometer (Applid Biosystems, Foster City, CA, USA).

Silica gel (200-300 mesh, Qingdao Marine Chemical, Qingdao, China) and Sephadex LH-20 (Amersham Biosciences, Uppsala, Sweden) were used for column chromatography. Fractions were monitored by TLC and spots were visualized by heating silica gel plates sprayed with $10 \% \mathrm{H}_{2} \mathrm{SO}_{4}$ in ethanol.

\section{Mushroom material}

The fresh fruiting bodies of $H$. erinaceum were collected on Funiu Mountain of He'nan Province, People's Republic of China, in July 2008. The fungal identification was made by Professor Jin-Wen Shen, Henan Agricultural University. A dried specimen was deposited in the Herbarium of Henan Agricultural University.

\section{Extraction and isolation}

The air-dried and powdered fruiting bodies of H. erinaceum (dry weight $2.0 \mathrm{~kg}$ ) were extracted with $\mathrm{MeOH}$ at room temperature to afford a deep brown gum (225 g). Then the $\mathrm{MeOH}$ extract was diluted with $\mathrm{H}_{2} \mathrm{O}$ and partitioned with $\mathrm{CHCl}_{3}$. The $\mathrm{CHCl}_{3}$ extract $(62 \mathrm{~g}$ ) was subjected to column chromatography eluting with petroleum ether/EtOAc. The fraction $(0.9 \mathrm{~g})$ from petroleum ether/ EtOAc $(20: 1, \mathrm{v} / \mathrm{v})$ was submitted for further purification by repeated Sephadex $\mathrm{LH}-20\left(\mathrm{CHCl}_{3} / \mathrm{MeOH}=1: 1, \mathrm{v} / \mathrm{v}\right)$ to give hericenone $\mathrm{F}(85 \mathrm{mg})$. The fraction $(1.2 \mathrm{~g})$ from petroleum ether/EtOAc $(19: 1, \mathrm{v} / \mathrm{v})$ was submitted for further purification by repeated Sephadex $\mathrm{LH}-20\left(\mathrm{CHCl}_{3} / \mathrm{MeOH}=1: 1, \mathrm{v} / \mathrm{v}\right)$ to give a mixture of hericenones $\mathrm{C}$ and I. Preparative HPLC with ODS column $\left(250 \times 30 \mathrm{~mm}, 5 \mathrm{ml} \mathrm{min}-1, \mathrm{MeOH} / \mathrm{H}_{2} \mathrm{O}=96: 4\right.$, detection at $\left.298 \mathrm{~nm}\right)$ to give hericenones $\mathrm{C}(56 \mathrm{mg})$ and $\mathrm{I}(18 \mathrm{mg})$.
The fraction $(1.6 \mathrm{~g})$ from petroleum ether/EtOAc $(10: 1, \mathrm{v} / \mathrm{v})$ was submitted for further purification by repeated Sephadex $\mathrm{LH}-20\left(\mathrm{CHCl}_{3} / \mathrm{MeOH}=1: 1\right.$, $\mathrm{v} / \mathrm{v})$ to give a mixture of hericenes $\mathrm{A}$ and D. Preparative HPLC with ODS column $\left(250 \times 30 \mathrm{~mm}, 5 \mathrm{ml} \mathrm{min}{ }^{-1}, \mathrm{MeOH} / \mathrm{H}_{2} \mathrm{O}=95: 5\right.$, detection at $\left.295 \mathrm{~nm}\right)$ to give hericenes $\mathrm{A}(150 \mathrm{mg})$ and $\mathrm{D}(35 \mathrm{mg})$.

Hericenone I. White oil: UV $\lambda_{\max }\left(\mathrm{CHCl}_{3}\right) 301 \mathrm{~nm}$. IR (KBr) 3463, 2918, 1742, 1669 and $1567 \mathrm{~cm}^{-1} .{ }^{1} \mathrm{H}$ and ${ }^{13} \mathrm{C}$ NMR spectra: see Table 1. HRESI-MS $m / z 619.6686\left(\mathrm{M}+\mathrm{Na}\right.$, calc. for $\left.\mathrm{C}_{37} \mathrm{H}_{56} \mathrm{O}_{6} \mathrm{Na} 619.6702\right)$.

Hericene D. White oil: UV $\lambda_{\max }\left(\mathrm{CHCl}_{3}\right) 296 \mathrm{~nm}$. IR( $\left.\mathrm{KBr}\right) 3446,2923,1754$ and $1571 \mathrm{~cm}^{-1} .{ }^{1} \mathrm{H}$ and ${ }^{13} \mathrm{C}$ NMR spectra: see Table 2. HRESI-MS $\mathrm{m} / \mathrm{z} 603.4026$ ( $\mathrm{M}+\mathrm{Na}$, calc. for $\mathrm{C}_{37} \mathrm{H}_{56} \mathrm{O}_{5} \mathrm{Na}$ 603.4031).

\section{Methanolysis of Hericene D and Hericenone I}

Hericenone I (5 mg) and Hericene D (5 mg) were dissolved with $0.1 \mathrm{M}$ methanolic $\mathrm{KOH}(5 \mathrm{ml})$ and stirred overnight at $4{ }^{\circ} \mathrm{C}$. Water was added to the reaction mixture, and the solution was neutralized with $0.1 \mathrm{M} \mathrm{HCl}$ and then extracted with hexane. The hexane layer was dried over $\mathrm{Na}_{2} \mathrm{SO}_{4}$, filtered and concentrated under reduced pressure to give the methyl ester of oleic acid and the methyl ester of linoleic acid, which were identified by GC-MS.

\section{Cell growth inhibition assay}

The growth inhibitor concentrations of compounds $\mathbf{1 - 5}$ on esophageal cancer EC109 cell line were determined by MTT assay. ${ }^{8}$ The EC109 cell was exposed to compounds at $1 \times 10^{-3}, 3 \times 10^{-4}$ and $1 \times 10^{-4} \mathrm{moll}^{-1}$ and each concentration was tested in triplicate. The OD was measured with a microplate reader at $570 \mathrm{~nm}$.

\section{ACKNOWLEDGEMENTS}

This project was supported by the National Natural Science Foundation of China (30901957) and Program for Excellent Young Teachers of He'nan Province.

1 Ueda, K. et al. Endoplasmic reticulum (ER) stress-suppressive compounds from scrap cultivation beds of the mushroom Hericium erinaceum. Biosci. Biotech. Biochem. 73, 1908-1910 (2009).

2 Yaoita, Y., Danbara, K. \& Kikuchi, M. Two new aromatic compounds from Hericium erinaceum (Bull.: $F_{R}$.) P ERS. Chem. Pharm. Bull. 53, 1202-1203 (2005).

3 Kawagishi, H., Ando, M. \& Mizuno, T. Hericenone A and B as cytotoxic principles from the mushroom Hericium erinaceum. Tetrahedron. Lett. 31, 373-376 (1990).

4 Kawagishi, H. et al. Hericenones C, D and E, stimulators of nerve growth factor(NGF)synthesis, from the mushroom Hericium erinaceum. Tetrahadron. Lett. 32, 4561-4564 (1991).

5 Kawagishi, H. et al. Chromans, hericenones F, G and $\mathrm{H}$ from the mushroom Hericium erinaceum. Phytochemistry 32, 175-178 (1993).

6 Alberto, A., Rosanna, C., Gianluca, N. \& Orso, V. P. Secondary mold metabolites: part 46. Hericenes A-C and erinapyrone $C$, new metabolites produced by the fungus Hericium erinaceum. J. Nat. Prod. 57, 602-606 (1995).

7 Ueda, K. et al. An endoplasmic reticulum (ER) stress-suppressive compounds and its analogues from the mushroom Hericium erinaceum. Bioorg. Med. Chem. 16, 9467-9470 (2008).

8 Mosmman, T. Rapid colorimetric assay for cellar growth and survival: application to proliferation and cytotoxicity assays. J. Immunol. Meth. 65, 55-63 (1983). 